\title{
Empirical mapping of ZrCu-based alloys with valence electrons versus transformation temperatures
}

\author{
Weihong $\mathrm{Gao}^{1}$, Xianglong Meng ${ }^{1 *}$, Gangbing Song ${ }^{2}$, Wei Cai ${ }^{1}$ and Liancheng Zhao ${ }^{1}$
}

\begin{abstract}
An empirical map of martensitic transformation temperatures versus average valence electrons per atom $\left(e_{\mathrm{v}}\right)$ a) and valence electron concentration $\left(c_{v}\right)$ was developed in order to design $\mathrm{ZrCu}$-based shape memory alloys (SMAs). The martensitic transformation temperatures of about 40 different alloys ( $\mathrm{Ni}, \mathrm{Co}, \mathrm{Hf}, \mathrm{Ag}$, $\mathrm{Ti}, \mathrm{Al}, \mathrm{Cr}$, etc.), covering nearly all possible replacements of $\mathrm{Zr}$ or $\mathrm{Cu}$, are exhibited. The relationship between transformation temperature and $c_{\mathrm{v}}$ or electron density ( $n$ ) was determined. The results indicate that the transformation temperatures of $\mathrm{ZrCu}$-based alloys gradually decrease until reaching an inflection point at $c_{\mathrm{v}}=0.218$, above which the transformation temperatures go down. A linear dependence of the transformation temperatures of $\mathrm{ZrCu}$-based alloys on the electron density is revealed by data-fitting. Under the guidance of these contour maps describing transformation temperatures and thermal hysteresis, a series of $\mathrm{ZrCu}$-based alloys that can function under different conditions can be designed.
\end{abstract}

Keywords: $\mathrm{ZrCu}$ alloy, shape memory alloys, valence electrons concentration, martensitic transformation temperatures

\section{INTRODUCTION}

Shape memory alloys (SMAs) exhibit unique shape memory effects and superelasticity behavior due to their martensitic transformation [1,2]. ZrCu-based alloys undergo a thermoelastic martensitic transformation from a B2 structure to two different monoclinic martensitic structures: one with a base structure (B19') with $\mathrm{P} 2{ }_{1} / m$ symmetry and the other with a superstructure (B33) with $\mathrm{Cmcm}$ symmetry $[3,4]$. They are considered as competitive high temperature shape memory alloys (HTSMAs) due to their low fabrication costs and high martensitic transformation temperatures, which are associated with favorable shape memory effects [5,6]. For example, a $\mathrm{Zr}_{42.3} \mathrm{Cu}_{29.9} \mathrm{Ni}_{11} \mathrm{Co}_{10.2} \mathrm{Ti}_{6.6}$ alloy can achieve a recoverable strain of $3.5 \%$ under $8 \%$ applied compressive strain, with a high martensitic starting transformation temperature $\left(M_{\mathrm{s}}\right)$ of $450 \mathrm{~K}$ [4]. In addition, $\mathrm{ZrCu}$-based bulk metallic glass (BMG) matrix composites show enhanced plasticity and overall work hardening under compressive loading because the B2-structured nanocrystals undergo a martensitic transformation during deformation $[7,8]$. Therefore, it is necessary to design the chemical composition of such materials to control the martensitic transformation temperatures, in order to acquire high transformation temperatures in HTSMA devices or to obtain B2 phase-BMG composites for applied use $[9,10]$.

The mechanism that allows alloying elements to change their transformation temperatures is dependent upon the electronic structures and the interatomic bonding forces within such alloys [11]. The valence electrons contributed by $\mathrm{s}+\mathrm{d}$ electrons of the transition metals, or $\mathrm{s}+\mathrm{p}$ electrons of the non-transition metals, act as adhesives during metallic bonding $[12,13]$. The strength of this adhesion, which depends on the number $\left(e_{\mathrm{v}} / \mathrm{a}\right)$, concentration $\left(c_{\mathrm{v}}\right)$, density $(n)$ of valence electrons, is relevant to the transformation temperatures of SMAs [11-16]. For ZrCu-based alloys, the relationship between transformation temperature and electronic structure has yet to be quantified, and therefore a guiding empirical map is necessary to design and optimize the central properties in $\mathrm{ZrCu}$-based alloys. In this paper, we have examined the number $\left(e_{\mathrm{v}} / \mathrm{a}\right)$, concentration $\left(c_{\mathrm{v}}\right)$ and density $(n)$ of valence electrons as correlates with the transformation temperatures of various $\mathrm{ZrCu}$-based alloys. Understanding such correlations would significantly benefit the design of $\mathrm{ZrCu}$-based alloys for different application backgrounds.

\section{MATERIALS AND EXPERIMENTAL PROCEDURE}

To adjust the $\mathrm{Zr} / \mathrm{Cu}$ ratio through substitutions of $\mathrm{Zr}$ or $\mathrm{Cu}$ with $\mathrm{Hf}, \mathrm{Co}, \mathrm{Ti}, \mathrm{Ag}, \mathrm{Ni}, \mathrm{Al}$ or $\mathrm{Cr}, \mathrm{ZrCu}$-based alloys were melted using high-purity metals in a non-consumed vacuum arc furnace under Ar. The ingots were then melted six more times to ensure compositional homogeneity (turning the button $180^{\circ}$ for each repetition). The samples were annealed in vacuum quartz tubes at $1073 \mathrm{~K}$ for

\footnotetext{
${ }^{1}$ School of Materials Science and Engineering, Harbin Institute of Technology, Harbin 150001, China

${ }^{2}$ Department of Mechanical Engineering, University of Houston, Houston TX 77204-4006, USA

* Corresponding author (email: xlmeng@hit.edu.cn)
} 
$4 \mathrm{~h}$, followed by quenching with water. The phase transformation temperatures of the alloys were determined by differential scanning calorimetry (DSC), using a Diamond DSC calorimeter with a heating/cooling rate of $20 \mathrm{~K} \mathrm{~min}^{-1}$. Our experimental data, together with previously reported transformation temperatures [4,17-22] of about 40 different alloys covering nearly all replacement elements of $\mathrm{Zr}$ or $\mathrm{Cu}$, are listed in Table 1. Phase purity and crystal structures were determined by X-ray diffraction (XRD) using $\mathrm{Cu} \mathrm{Ka}$ radiation at room temperature.

\section{RESULTS AND DISCUSSION}

The number of valence electrons can be calculated based on the contributions of the $s+d$ electrons from the transition metals, or the $s+p$ electrons of the non-transition metals [12]. Since both $\mathrm{Zr}$ and $\mathrm{Cu}$ are transition metals, the number of valence electrons $\left(e_{\mathrm{v}}\right)$ for $\mathrm{Zr}$ and $\mathrm{Cu}$ are $4\left(5 s^{2} 4 d^{2}\right)$ and $11\left(4 s^{1} 3 d^{10}\right)$, respectively. Therefore, the average valence electrons per atom $\left(e_{\mathrm{v}} / \mathrm{a}\right)$ in the equiatomic $\mathrm{ZrCu}$ alloy is 7.5 . The valence electron concentration $\left(c_{\mathrm{v}}\right)$ is defined as the number of valence electrons in the alloy divided by the total electrons in the alloy as calculated by using the following equations [13]

$$
\begin{gathered}
\frac{e_{\mathrm{v}}}{\mathrm{a}}=f_{\mathrm{Zr}} e_{\mathrm{v}}^{\mathrm{Zr}}+f_{\mathrm{Cu}} e_{\mathrm{v}}^{\mathrm{Cu}}+f_{\mathrm{T}} e_{\mathrm{v}}^{\mathrm{T}}+f_{\mathrm{Q}} e_{\mathrm{v}}^{\mathrm{Q}}, \\
c_{\mathrm{v}}=\frac{f_{\mathrm{Zr}} e_{\mathrm{v}}^{\mathrm{Zr}}+f_{\mathrm{Cu}} e_{\mathrm{v}}^{\mathrm{Cu}}+f_{\mathrm{T}} e_{\mathrm{v}}^{\mathrm{T}}+f_{\mathrm{Q}} e_{\mathrm{v}}^{\mathrm{Q}}}{f_{\mathrm{Zr}} Z_{\mathrm{Zr}}+f_{\mathrm{Cu}} Z_{\mathrm{Cu}}+f_{\mathrm{T}} Z_{\mathrm{T}}+f_{\mathrm{Q}} Z_{\mathrm{Q}}},
\end{gathered}
$$

where $f_{\mathrm{Zr}}, f_{\mathrm{Cu}}, f_{\mathrm{T}}$, and $f_{\mathrm{Q}}$ represent the atomic fractions of elements in the alloy for $\mathrm{Zr}, \mathrm{Cu}$, ternary, and quaternary elements, respectively. $e_{\mathrm{v}}^{\mathrm{Zr}}, e_{\mathrm{v}}^{\mathrm{Cu}}, e_{\mathrm{v}}^{\mathrm{T}}$, and $e_{\mathrm{v}}^{\mathrm{Q}}$ are the corresponding number of valence electrons of $\mathrm{Zr}, \mathrm{Cu}$, and the ternary and quaternary elements, respectively. $\mathrm{Z}_{\mathrm{Zr}}, \mathrm{Z}_{\mathrm{Cu}}, \mathrm{Z}_{\mathrm{T}}$ and $\mathrm{Z}_{\mathrm{Q}}$ represent the atomic numbers of $\mathrm{Zr}, \mathrm{Cu}$, and the ternary and quaternary elements, respectively. The variations of $M_{\mathrm{s}} v s . e_{\mathrm{v}} / \mathrm{a}$ and $c_{\mathrm{v}}$ are plotted in Figs $1 \mathrm{a}$ and $\mathrm{b}$, respectively. The calculated $e_{\mathrm{v}} / \mathrm{a}$ values for $\mathrm{ZrCu}$-based alloys range from 6.7 to 7.85 , while $c_{\mathrm{v}}$ ranges from 0.2036 to 0.2312 . The transformation temperatures in $\mathrm{ZrCu}$-based alloys are found mostly in a number of valence electrons per atom in the range of $7.0 \leqslant e_{\mathrm{v}} / \mathrm{a} \leqslant 7.5$. The transformation temperature data are scattered and no clear relationship between the transformation temperatures and the $e_{\mathrm{v}} / \mathrm{a}$ or $c_{\mathrm{v}}$ was observed, although the highest transformation temperatures are observed within this range. However, the transformation temperatures in $\mathrm{ZrCu}$-based SMAs seem to be a function of both $e_{\mathrm{v}} / \mathrm{a}$ and $c_{\mathrm{v}}$. A contour map of martensitic transformation temperature $M_{\mathrm{s}}$ in a wide $e_{\mathrm{v}} / \mathrm{a}$ and $c_{\mathrm{v}}$ range is summarized in Fig. 1c. According to the contours of the two-variable polynomial fitting curve, higher temperature for $\mathrm{ZrCu}$-based SMAs can be achieved at $e_{\mathrm{v}} /$ a values of 7.1 to 7.4 , and in a $c_{\mathrm{v}}$ range of 0.205 to 0.220 .

Apart from the effects of $e_{\mathrm{v}} / \mathrm{a}$, the variations of $M_{\mathrm{s}}$ and $A_{\mathrm{s}}$ vs. $c_{\mathrm{v}}$ at $e_{\mathrm{v}} / \mathrm{a}=7.5$ is shown in Fig. 2 . Among the alloys at the same $e_{\mathrm{v}}$ /a value (7.5), the transformation temperatures are very sensitive to $c_{\mathrm{v}}$. For $\mathrm{ZrCu}$-based alloys within the statistical data, both $M_{\mathrm{s}}$ and $A_{\mathrm{s}}$ decrease monotonously from temperatures as high as $450 \mathrm{~K}(575 \mathrm{~K})$ down to as low as $275 \mathrm{~K}(450 \mathrm{~K})$ for alloys at $c_{\mathrm{v}}=0.206-0.224$. This decreased rate appears to change at $c_{\mathrm{v}}=0.218$. Further increases of $c_{\mathrm{v}}$ cause both $M_{\mathrm{s}}$ and $A_{\mathrm{s}}$ to sharply decrease. The general trend of martensitic transformation equilibrium temperature $T_{0}$ $\left(T_{0}=\left(M_{\mathrm{p}}+A_{\mathrm{p}}\right) / 2\right.$, where $M_{\mathrm{p}}$ and $A_{\mathrm{p}}$ represent the peaks of the martensitic and reverse transformations, respectively) vs. $c_{\mathrm{v}}$ is similar to $A_{\mathrm{s}}$ and $M_{\mathrm{s}}$, as shown in Fig. 2c. However, when $e_{\mathrm{v}} / \mathrm{a} \neq 7.5$, no obvious trend between the transformation temperatures and $c_{\mathrm{v}}$ is present.

The transformation temperature of $\mathrm{ZrCu}$-based alloys decreases with increasing $c_{\mathrm{v}}$. An increased $c_{\mathrm{v}}$ leads to strengthened bonds, and in turn an enhancement of the B2 structure stability. The valence electron concentration in this structure is mainly determined by $\mathrm{d}-\mathrm{d}$ interactions of the $\mathrm{Cu}$ and $\mathrm{Zr}$ electrons [25]. This stabilization originates from the deformation splitting of the electronic density of states peak above the Fermi level induced by the $d-d$ hybridization between $\mathrm{Zr}$ and $\mathrm{Cu}$ sites, which forms an additional occupied electron state close to $E_{\mathrm{F}}$ and increases the total energy of the B2 phase [26]. The $d-d$ hybridization between $\mathrm{Zr}$ and $\mathrm{Cu}$ sites becomes stronger as the valence electron concentration increases, which increases the total energy; likewise as the stability of the B2 structure strengthens, $M_{\mathrm{s}}$ decreases. Moreover, a higher valence electron concentration usually results in higher bulk and shear moduli, which for solid state materials is a measure of resistance to volume change and a measure of resistance to shape change, respectively [11-13]. In summary, higher $c_{\mathrm{v}}$ values lead to lower transformation temperatures.

In considering the crystal structure of $\mathrm{ZrCu}$-based alloys, valence electron density $(n)$ which is a function of the number of valence electron $\left(e_{\mathrm{v}} / \mathrm{a}\right)$ and the unit volume of the crystal $\left(V_{\text {cell }}\right)$, is a factor for describing transformation temperature variations. This relationship can be expressed as [27]

$$
n=\frac{e_{\mathrm{v}} / \mathrm{a}}{V_{\text {cell }}} \cdot N,
$$

where $N$ represents the average number of atoms contained in a unit cell. In order to study the relationship between va- 
Table 1 The number of valence electrons per atom $e_{\mathrm{v}} / \mathrm{a}$, valence electrons concentration $c_{\mathrm{v}}$, martensite start transformation temperature $M_{\mathrm{s}}$, austenite start transformation temperature $A_{\mathrm{s}}$ and thermal hysteresis $\left(\Delta T=A_{\mathrm{p}}-M_{\mathrm{p}}\right)$ for $\mathrm{ZrCu}$-based shape memory alloys

\begin{tabular}{|c|c|c|c|c|c|c|}
\hline Alloy & $M_{\mathrm{s}}(\mathrm{K})$ & $A_{\mathrm{s}}(\mathrm{K})$ & $\Delta T(\mathrm{~K})$ & $e_{\mathrm{v}} / \mathrm{a}$ & $c_{\mathrm{v}}$ & Ref. \\
\hline $\mathrm{Zr}_{50} \mathrm{Cu}_{50}$ & 358 & 529 & 182 & 7.5 & 0.2174 & Present study \\
\hline $\mathrm{Zr}_{50} \mathrm{Cu}_{50}$ & 413 & - & - & 7.5 & 0.2174 & {$[17]$} \\
\hline $\mathrm{Zr}_{50} \mathrm{Cu}_{50}$ & 323 & 531 & 190 & 7.5 & 0.2174 & {$[23]$} \\
\hline $\mathrm{Zr}_{50} \mathrm{Cu}_{50}$ & 368 & 503 & - & 7.5 & 0.2174 & {$[18]$} \\
\hline $\mathrm{Zr}_{55} \mathrm{Cu}_{45}$ & 401 & 532 & - & 7.15 & 0.214 & {$[18]$} \\
\hline $\mathrm{Zr}_{52} \mathrm{Cu}_{48}$ & 431 & 526 & - & 7.36 & 0.216 & {$[18]$} \\
\hline $\mathrm{Zr}_{48} \mathrm{Cu}_{52}$ & 433 & 519 & - & 7.64 & 0.2229 & {$[18]$} \\
\hline $\mathrm{Zr}_{45} \mathrm{Cu}_{55}$ & 411 & 516 & - & 7.85 & 0.2312 & {$[18]$} \\
\hline $\mathrm{Zr}_{48.2} \mathrm{Cu}_{50} \mathrm{Ti}_{1.8}$ & 383 & 561 & 178 & 7.5 & 0.2195 & {$[24]$} \\
\hline $\mathrm{Zr}_{47.2} \mathrm{Cu}_{50} \mathrm{Ti}_{2.8}$ & 323 & 516 & 193 & 7.5 & 0.2206 & {$[24]$} \\
\hline $\mathrm{Zr}_{46.5} \mathrm{Cu}_{50} \mathrm{Ti}_{3.5}$ & 308 & 528 & 220 & 7.5 & 0.2214 & {$[24]$} \\
\hline $\mathrm{Zr}_{44.5} \mathrm{Cu}_{50} \mathrm{Ti}_{5.5}$ & 283 & 453 & 170 & 7.5 & 0.2238 & {$[24]$} \\
\hline $\mathrm{Zr}_{49.6} \mathrm{Cu}_{28.2} \mathrm{Ni}_{6.8} \mathrm{Co}_{15.4}$ & 485 & 526 & 82.5 & 7.15 & 0.2098 & {$[4]$} \\
\hline $\mathrm{Zr}_{50} \mathrm{Cu}_{25} \mathrm{Ni}_{2.5} \mathrm{Co}_{22.5}$ & 398 & 422 & 53 & 7.025 & 0.2101 & Present study \\
\hline $\mathrm{Zr}_{50} \mathrm{Cu}_{25} \mathrm{Ni}_{5} \mathrm{Co}_{20}$ & 483 & 507 & 57 & 7.05 & 0.207 & Present study \\
\hline $\mathrm{Zr}_{50} \mathrm{Cu}_{25} \mathrm{Ni}_{7.5} \mathrm{Co}_{17.5}$ & 564 & 568 & 60 & 7.075 & 0.2076 & Present study \\
\hline $\mathrm{Zr}_{50} \mathrm{Cu}_{25} \mathrm{Ni}_{10} \mathrm{Co}_{15}$ & 603 & 681 & 98 & 7.1 & 0.2082 & Present study \\
\hline $\mathrm{Zr}_{42.3} \mathrm{Cu}_{29.9} \mathrm{Ni}_{11} \mathrm{Co}_{10.2} \mathrm{Ti}_{6.6}$ & 410 & 450 & 70 & 7.26 & 0.2208 & {$[4]$} \\
\hline $\mathrm{Zr}_{50} \mathrm{Cu}_{48} \mathrm{Ni}_{2}$ & 464 & 561 & 110 & 7.48 & 0.2169 & Present study \\
\hline $\mathrm{Zr}_{50} \mathrm{Cu}_{46} \mathrm{Ni}_{4}$ & 510 & 604 & 111 & 7.46 & 0.2165 & Present study \\
\hline $\mathrm{Zr}_{50} \mathrm{Cu}_{44} \mathrm{Ni}_{6}$ & 533 & 653 & 137 & 7.44 & 0.216 & Present study \\
\hline $\mathrm{Zr}_{50} \mathrm{Cu}_{42} \mathrm{Ni}_{8}$ & 562 & 682 & 141 & 7.42 & 0.2156 & Present study \\
\hline $\mathrm{Zr}_{50} \mathrm{Cu}_{40} \mathrm{Ni}_{10}$ & 587 & 722 & 136 & 7.40 & 0.2151 & Present study \\
\hline $\mathrm{Zr}_{50} \mathrm{Cu}_{45} \mathrm{Ni}_{5}$ & 433 & 608 & - & 7.45 & 0.2161 & {$[23]$} \\
\hline $\mathrm{Zr}_{50} \mathrm{Cu}_{40} \mathrm{Ni}_{10}$ & 536 & 700 & - & 7.4 & 0.2151 & {$[23]$} \\
\hline $\mathrm{Zr}_{50.59} \mathrm{Cu}_{29.56} \mathrm{Ni}_{19.85}$ & 497 & 597 & - & 7.26 & 0.2113 & {$[19]$} \\
\hline $\mathrm{Zr}_{50} \mathrm{Cu}_{45} \mathrm{Cr}_{5}$ & 341 & 432 & - & 7.25 & 0.2117 & {$[20]$} \\
\hline $\mathrm{Zr}_{50} \mathrm{Cu}_{49.5} \mathrm{Ag}_{0.5}$ & 433 & 526 & 112 & 7.5 & 0.2168 & Present study \\
\hline $\mathrm{Zr}_{50} \mathrm{Cu}_{49} \mathrm{Ag}_{1}$ & 436 & 528 & 118 & 7.5 & 0.2163 & Present study \\
\hline $\mathrm{Zr}_{50} \mathrm{Cu}_{48} \mathrm{Ag}_{2}$ & 415 & 515 & 120 & 7.5 & 0.2151 & Present study \\
\hline $\mathrm{Cu}_{50} \mathrm{Zr}_{48} \mathrm{Hf}_{2}$ & 440 & 540 & 128 & 7.5 & 0.2134 & Present study \\
\hline $\mathrm{Cu}_{50} \mathrm{Zr}_{46} \mathrm{Hf}_{4}$ & 443 & 547 & 132 & 7.5 & 0.2096 & Present study \\
\hline $\mathrm{Cu}_{50} \mathrm{Zr}_{44} \mathrm{Hf}_{6}$ & 442 & 557 & 140 & 7.5 & 0.2059 & Present study \\
\hline $\mathrm{Cu}_{50} \mathrm{Zr}_{42} \mathrm{Hf}_{8}$ & 436 & 577 & 165 & 7.5 & 0.2024 & Present study \\
\hline $\mathrm{Zr}_{50} \mathrm{Cu}_{48} \mathrm{Co}_{2}$ & 410 & 485 & - & 7.46 & 0.2165 & {$[21]$} \\
\hline $\mathrm{Zr}_{50} \mathrm{Cu}_{47} \mathrm{Co}_{3}$ & 396 & 470 & - & 7.44 & 0.216 & {$[21]$} \\
\hline $\mathrm{Zr}_{50} \mathrm{Cu}_{46} \mathrm{Co}_{4}$ & 375 & 431 & - & 7.42 & 0.2156 & {$[21]$} \\
\hline $\mathrm{Zr}_{50} \mathrm{Cu}_{45} \mathrm{Co}_{5}$ & 355 & 419 & - & 7.40 & 0.2151 & {$[21]$} \\
\hline $\mathrm{Zr}_{50} \mathrm{Cu}_{48} \mathrm{Al}_{2}$ & 415 & 503 & - & 7.34 & 0.2147 & {$[22]$} \\
\hline $\mathrm{Zr}_{50} \mathrm{Cu}_{46} \mathrm{Al}_{4}$ & 362 & 474 & - & 7.18 & 0.212 & {$[22]$} \\
\hline $\mathrm{Zr}_{50} \mathrm{Cu}_{44} \mathrm{Al}_{6}$ & 311 & 464 & - & 7.02 & 0.2093 & {$[22]$} \\
\hline $\mathrm{Zr}_{50} \mathrm{Cu}_{42} \mathrm{Al}_{8}$ & 309 & 455 & - & 6.86 & 0.2065 & {$[22]$} \\
\hline $\mathrm{Zr}_{50} \mathrm{Cu}_{40} \mathrm{Al}_{10}$ & 306 & 455 & - & 6.7 & 0.2036 & {$[22]$} \\
\hline
\end{tabular}



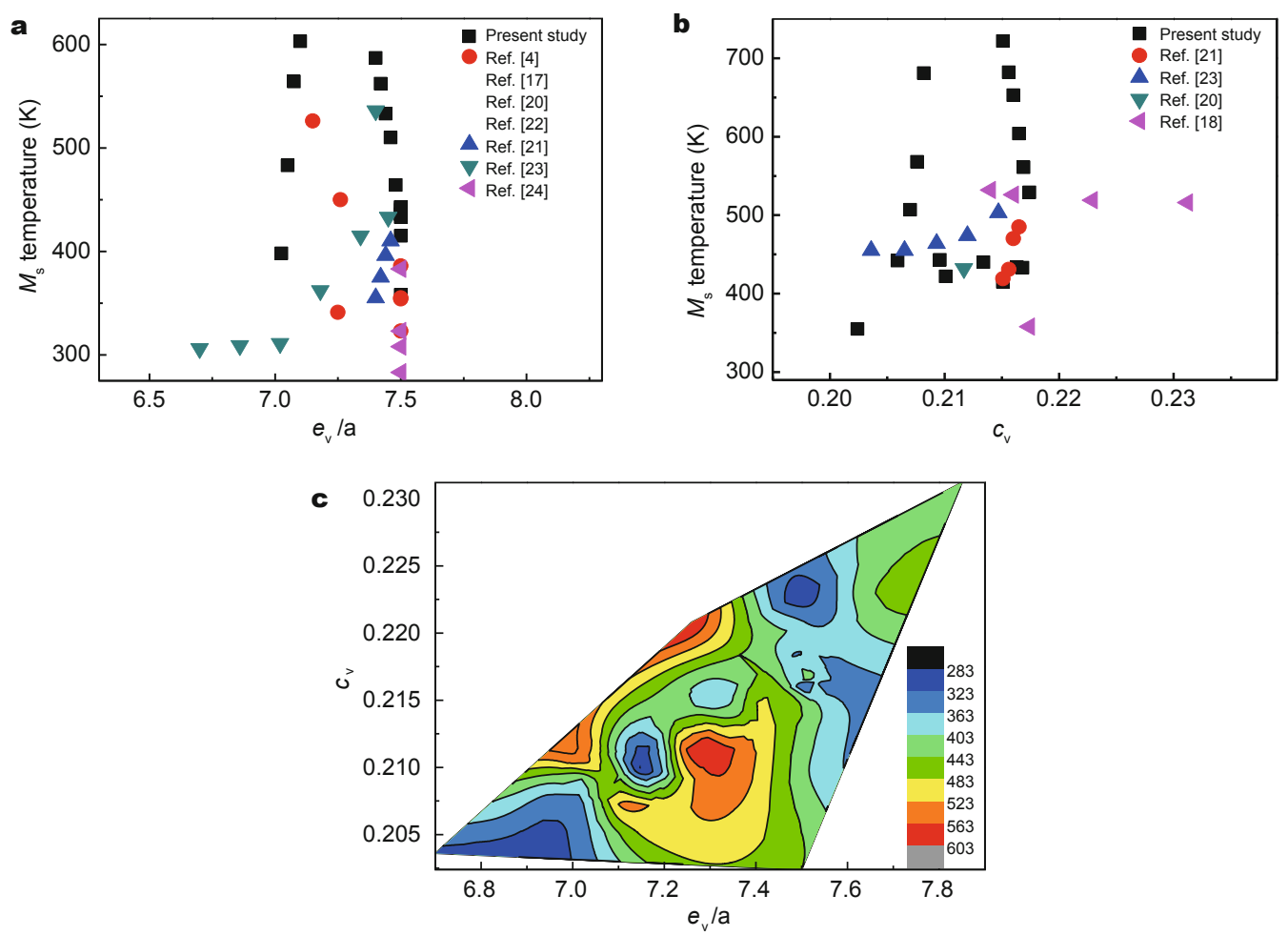

Figure 1 Variations of martensitic transformation start temperature $\left(M_{s}\right)$ (most datas from our studies while partial from Refs. $\left.[4,17,18,20-24]\right)$ with the number of valence electrons per atom $\left(e_{v} / \mathrm{a}\right)(\mathrm{a})$ and valence electron concentration $\left(c_{\mathrm{v}}\right)(\mathrm{b})$ of $\mathrm{ZrCu}$-based shape memory alloys, (c) contour views of the curve fitted $M_{\mathrm{s}}$ versus $e_{\mathrm{v}} / \mathrm{a}$ and $c_{\mathrm{v}}$.
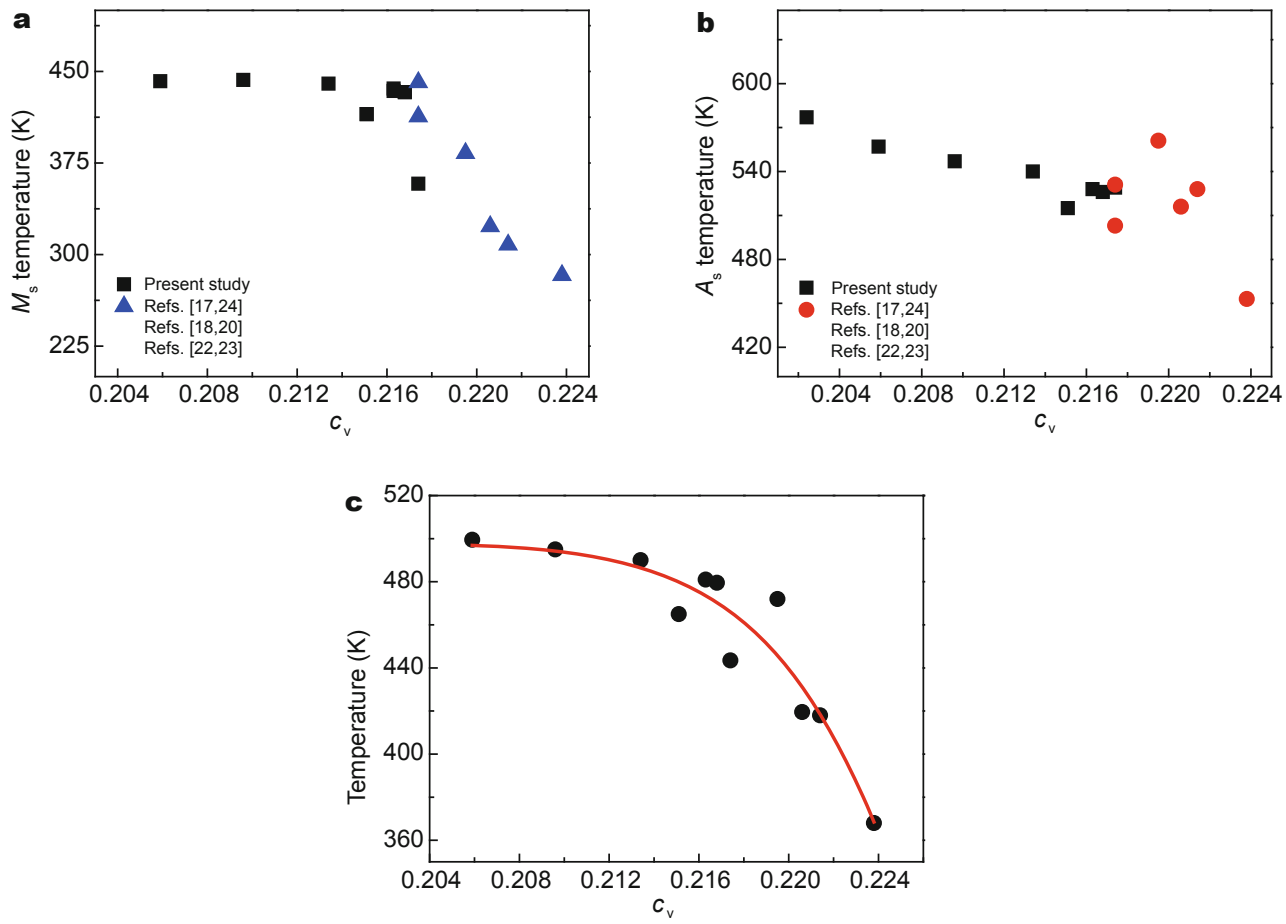

Figure 2 Variation of Martensite start temperatures $M_{\mathrm{s}}$ (a) and Austenite start temperatures $A_{\mathrm{s}}$ (b) versus different alloy elements with $e_{\mathrm{v}} / \mathrm{a}=7.5$; (c) the relationship between martensitic transformation equilibrium temperature $\left(T_{0}\right)$ and valence electrons concentration $c_{v}$. 
lence electron densities and transformation temperatures, $\mathrm{Zr}-\mathrm{Cu}-\mathrm{Ni}$ and $\mathrm{Zr}-\mathrm{Cu}-\mathrm{Hf}$ alloys are designed and partial data are selected from Ref. [21]. All the diffraction peaks of the samples can be well indexed to monoclinic martensite (a base structure B19' and a superstructure B33). The B33 martensite phase is the superstructure of the basic structure B19' martensite and consists of four units of B19' structures [28]. Therefore, the variation tendency of the unit-cell volume is based on the lattice parameter of B19' martensite in $\mathrm{Zr}-\mathrm{Cu}-\mathrm{Ni}$ and $\mathrm{Zr}-\mathrm{Cu}-\mathrm{Hf}$ alloys. A linear relationship between the transformation temperatures $\left(A_{\mathrm{s}}\right.$ and $M_{\mathrm{s}}$ ) and the electron density is shown in Fig. 3. In order to better determine the temperature scale corresponding to electron density changes, trends were estimated for the effect of $n$ on $T_{0}$ as shown in Fig. 3c. This analysis allows us to write the empirical formula $T_{0}=2158-3826 n$, where $T_{0}$ is the martensitic transformation equilibrium temperature. Based on this equation, $T_{0}$ above $1000 \mathrm{~K}$ (corresponding to the potential HTSMAs with high transformation temperature) can be obtained if $n<0.303$, while $T_{0}$ close to room temperature can be achieved when $n \approx 0.486$.

It is particularly notable that the transformation hysteresis of $\mathrm{ZrCu}$-based alloys is very broad (183 $\mathrm{K}$ for $\mathrm{Zr}_{50} \mathrm{Cu}_{50}$ alloy), and the martensitic transformation can be considered as non-thermoelastic [29]. The wide thermal hysteresis of SMAs may result in longer response times, as well as small sensitivity and frequency values which are not anticipated for actuator applications. The contour map for the thermal hysteresis behavior $v s . c_{\mathrm{v}}$ and $e_{\mathrm{v}} / \mathrm{a}$ is shown in Fig. 4. The darkest area represents a very small thermal hysteresis (about $50 \mathrm{~K}$ ). When $c_{\mathrm{v}}$ is held constant, the thermal hysteresis distinctly becomes narrower as $e_{\mathrm{v}} / \mathrm{a}$ decreases. The small thermal hysteresis is a characteristic of the thermoelastic transformation in SMAs. Normally, SMAs with thermoelastic transformations can exhibit favorable shape memory effects. For example, a $\mathrm{Zr}_{42.3} \mathrm{Cu}_{29.9} \mathrm{Ni}_{11} \mathrm{Co}_{10.2} \mathrm{Ti}_{6.6}$ alloy with a smaller thermal hysteresis $(70 \mathrm{~K})$ than other $\mathrm{ZrCu}$-based alloys can achieve a shape memory effect of approximately $3.5 \%$ [4]. In addition, this smaller thermal hysteresis is accompanied by a small energy dissipation derived from the friction of domain rearrangements and phase boundary migrations. Thus, this map demonstrates that to acquire small thermal hysteresis in $\mathrm{ZrCu}$-based alloys, a relatively small $e_{\mathrm{v}} /$ a value is necessary. According to the contours (Figs 1c and 4) of the two-variable polynomial fitting curves, higher transformation temperatures

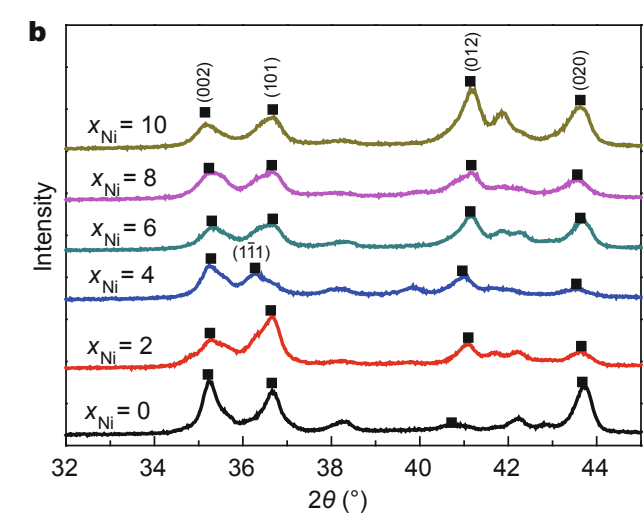

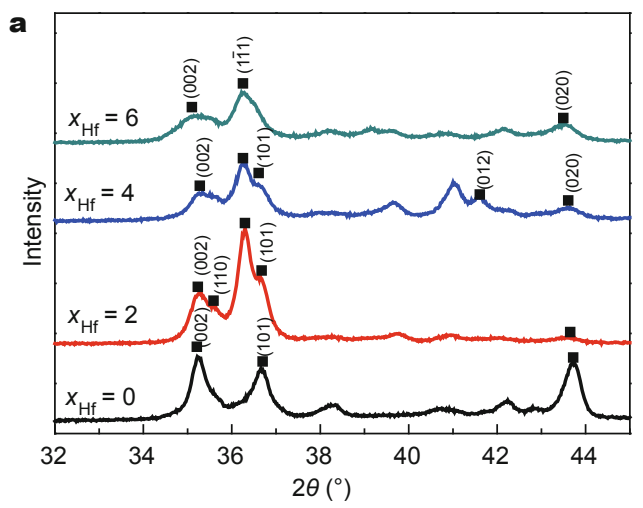

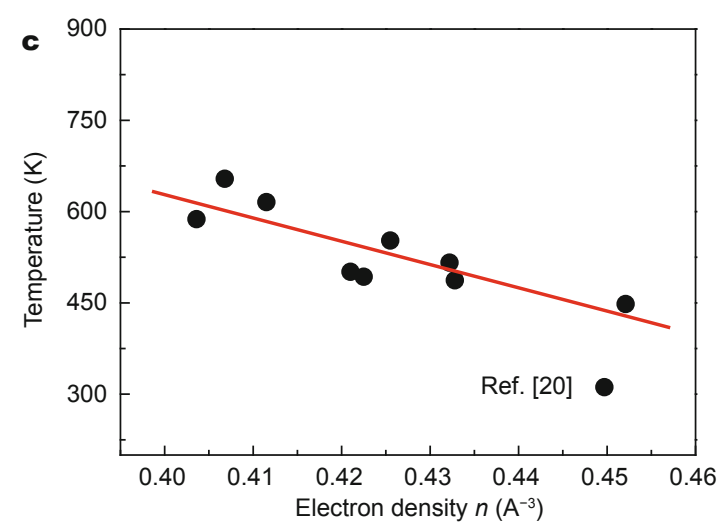

Figure 3 The XRD patterns of (a) $\mathrm{Zr}_{50} \mathrm{Cu}_{50-x} \mathrm{Ni}_{x}(x=0,2,4,6,8,10)$ and (b) $\mathrm{Cu}_{50} \mathrm{Zr}_{50-x} \mathrm{Hf}_{x}(x=0,2,4,6)$ alloys at room temperature. (c) The relationship between martensitic transformation equilibrium temperature $\left(T_{0}\right)$ and electron density $(n)$. (Most data from our studies while partial from Ref. [20]). 


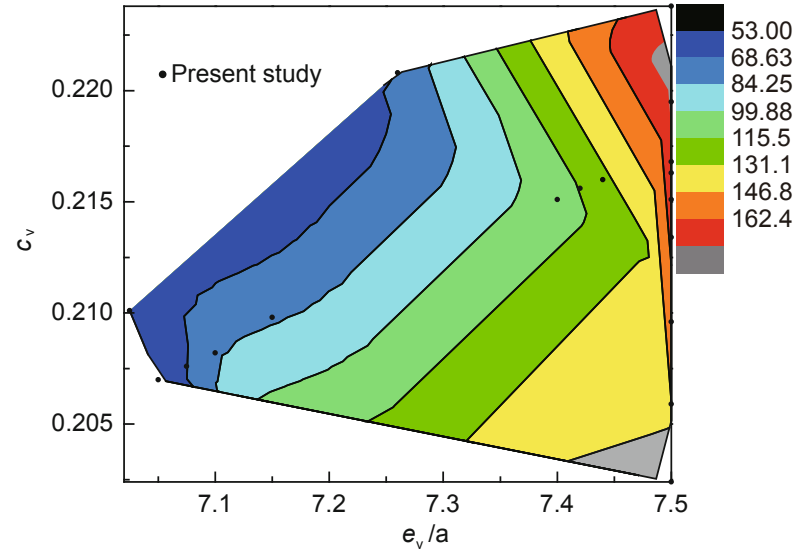

Figure 4 Contour views of the curve fitted thermal hysteresis (Most data from our studies while partial from Refs. [4,24,28]).

and smaller thermal hysteresis in $\mathrm{ZrCu}$-based alloys can be achieved with the $e_{\mathrm{v}} /$ a values between 7.1 to 7.2 , and $c_{\mathrm{v}}$ values between 0.207 to 0.220 , respectively.

\section{CONCLUSIONS}

In summary, an empirical map describing transformation temperature $v$ s. $e_{\mathrm{v}} / \mathrm{a}$ and $c_{\mathrm{v}}$ is described for designing $\mathrm{Zr}$ $\mathrm{Cu}$-based systems. The transformation temperatures of $\mathrm{Zr}$ $\mathrm{Cu}$-based alloys decrease with increasing $c_{\mathrm{v}}$ when $e_{\mathrm{v}} / \mathrm{a}=7.5$, which can be interpreted that increased valence electron concentration related to the total density of states at the Fermi level leads to the stabilization of B2 structures. A linear relationship between transformation temperature and valence electron density was also determined. This study yields further understanding of the influence that chemical composition has on the transformation temperatures of $\mathrm{ZrCu}$-based alloys, enabling more effective alloy design.

Received 14 January 2016; Accepted 23 February 2016; published online 29 February 2016

1 Otsuka K, Wayman CM. Shape Memory Materials. Cambridge: Cambridge University Press, 1998

2 Emre A, Osman EO, Haluk EK. Experimental investigation and modeling of the loading rate and temperature dependent superelastic response of a high performance shape-memory alloy. Smart Mater Struct, 2015, 24: 075020

3 Ma J, Karaman I, Noebe RD. High temperature shape memory alloy. Int Mater Rev, 2010, 55: 257-315

4 Firstov GS, Humbeeck JV, Koval YN. Comparison of high temperature shape memory behavior for $\mathrm{ZrCu}$-based, Ti-Ni-Zr and $\mathrm{Ti}-\mathrm{Ni}$ Hf alloys. Scr Mater, 2004, 50: 243-248

5 Meng XL, Gao WH, Gao ZY, Cai W, Zhao LC. Substructure and interface of the superstructure martensitic in $\mathrm{Zr}_{50} \mathrm{Cu}_{50}$ high temperature shape memory alloy. Mater Lett, 2014, 117: 221-224

6 Gao WH, Meng XL, Cai W, Zhao LC. Martensite structure and phase transformation of quaternary $\mathrm{ZrCuAlCo}$ high temperature shape memory alloys. J. Alloys Comp, 2014, 607: 99-103

7 Hofmann DC. Shape memory bulk metallic glass composites. Science, 2010, 329: 1294

8 Pauly S, Liu G, Wang G, et al. Modeling deformation behavior of $\mathrm{Cu}-\mathrm{Zr}$-Al bulk metallic glass matrix composites. Appl Phys Lett, 2009, 95: 101906

9 Song GB, Ma N, Lee HJ, Arnold S. Design and control of a proofof-concept variable area exhaust nozzle using shape-memory alloy actuators. Smart Mater Struct, 2007, 16: 1342-1347

10 Glock S, Michaud VT. Thermal and damping behaviour of magnetic shape memory alloy composites. Smart Mater Struct, 2015, 24: 065025

11 Zarinejad M, Liu Y. Dependence of transformation temperatures of NiTi-based shape-memory alloys on the number and concentration of valence electrons. Adv Funct Mater, 2008, 18: 1-6

12 Zarinejad M, Liu Y, Tong YX. Transformation temperature changes due to second phase precipitation in NiTi-based shape memory alloys. Intermetallics, 2009, 17: 914-919

13 Zarinejad M, Liu Y. Dependence of Transformation Temperatures of Shape-memory Alloys on the Number and Concentration of Valence Electrons. New York: Nova Science Publishers Inc, 2010: 339-360

14 Huang YJ, Hu QD, Li JG. Design in Ni-Mn-In magnetic shape-memory alloy using compositional maps. Appl Phys Lett, 2012, 101: 222403

15 Sutou Y, Imano Y, Koeda N, et al. Magnetic and martensitic transformations of $\mathrm{NiMnX}(\mathrm{X}=\mathrm{In}, \mathrm{Sn}, \mathrm{Sb})$...ferromagnetic shape memory alloys. Appl Phys Lett, 2004, 85: 4358

16 Jin X, Marioni M, Bono D, Allen SM, O’Handley RC. Empirical mapping of Ni-Mn-Ga properties with composition and valence electron concentration. J Appl Phys, 2002, 91: 8222-8224

17 Koval YN, Firstov GS, Kotko AV. Martensitic transformation and shape memory effect in $\mathrm{Zr}-\mathrm{Cu}$ intermetallic compound. Scr Metall et Mater, 1992, 27: 1611-1616

18 Biffi CA, Figini A, Tuissi A. Influence of compositional ratio on microstructure and martensitic transformation of CuZr shape memory alloys. Intermetallics, 2014, 46: 4-11

19 Firstov GS, Koval YN, Humbeeck JV, et al. Phase transformations in $\mathrm{Zr}-29.56$ at.\% $\mathrm{Cu}-19.85$ at.\%Ni melt-spun high-temperature shape memory alloy. Mater Sci Eng A, 2006, 438-440: 816-820

20 Biffi CA, Figini A, Tuissi A. CuZr based shape memory alloys: effect of $\mathrm{Cr}$ and $\mathrm{Co}$ on the martensitic transformation. Mater Sci Forum, 2013, 738-739: 167-171

21 Javida FA, Mattern N, Pauly S, Eckert J. Martensitic transformation and thermal cycling effect in Cu-Co-Zr alloys. J Alloys Comp, 2011, 509S: S334-S337

22 Meng FQ, Tsuchiya K, Ii Seiichiro, Yokoyama Y. Influence of Ni on stability of martensitic transformation in $\mathrm{Zr}_{50} \mathrm{Cu}_{50-x} \mathrm{Ni}_{x}$. J Alloys Comp, 2013, 577S: S136-S140

23 Meng FQ, Tsuchiya K, Yin FX, Ii S, Yokoyama Y. Influence of Al on stability of martensitic transformation in $\mathrm{Zr}_{50} \mathrm{Cu}_{50-x} \mathrm{Al}_{x^{*}}$ J Alloys Comp, 2012, 522: 136-140

24 Koval YN, Firstov GS, Kotko AV, Delaey L, Humbeeck JV. The influence of $\mathrm{Ni}$ and $\mathrm{Ti}$ on the martensitic transformation temperature and shape memory effect of the intermetallic compound $\mathrm{ZrCu}$. Scr Metall et Mater, 1994, 31: 799

25 Firstov GS, Timoshevskii AN, Koval YN, Kalkuta S, Humbeeck JV. Phase stability during martensitic transformation in $\mathrm{ZrCu}$ intermetallics: crystal and electronic structure aspects. ESOMAT, 2009, 02008

26 Zhalko-Titarenkmo AV, Yevlashinva ML, Antonovb VN, et al. Electronic and crystal structure of the $\mathrm{ZrCu}$ intermetallic compound close to the point of structural transformation. Phys Status Solidi 
B, 1994, 184: 122

27 Wang RL, Yan JB, Xiao HB, et al. Effect of electron density on the martensitic transition in Ni-Mn-Sn alloys. J Alloys Comp, 2011, 509: 6834-6837

28 Seo JW, Schryvers D. TEM investigation of the microstructure and defects of CuZr martensite. Part I: morphology and twin systems. Acta Mater, 1998, 46: 1165-1175

29 Firstov GS, Humbeeck JV, Koval YN. Peculiarities of the martensitic transformation in $\mathrm{ZrCu}$ intermetallic compound-potential high temperature SMA. J Phys IV, 2001, 11: 481-486

Acknowledgments This work was supported by the National Natural
Science Foundation of China (51171052 and 51322102), the Key Projects of Chinese National Programs for Fundamental Research and Development (2011CB012904 and 2012CB619400), the Doctoral Program Foundation of Institutions of Higher Education of China (20112302130006) and the Fundamental Research Funds for the Central Universities (HIT. BRET III 201201).

Author contributions Gao W, Meng X, Song G, Cai W and Zhao L designed the research. Gao W performed the experiments. Gao W and Meng X wrote the paper.

Conflict of interest The authors declear that they have no conflict of interest.

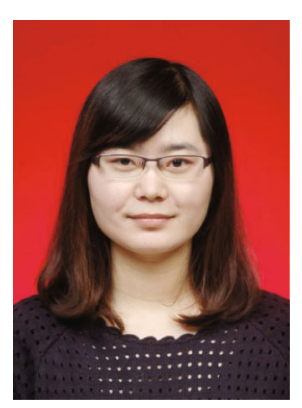

Weihong Gao is currently a PhD candidate in the Department of Material Physics and Chemistry at Harbin Institute of Technology, China. She received his BSc degree and MSc degree majored in material physics and chemistry at Harbin Engineering University. Her current research is mainly on martensite phase transformation; microstructure and interface of high temperature shape memory alloys.

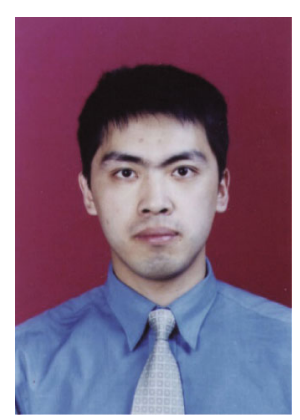

Xianglong Meng is currently a professor at Harbin Institute of Technology. He obtained his PhD degree from Harbin Institute of Technology in 2004. His research interests focus mainly on high temperature shape memory alloys, martensitic transformation and microstructure.

\section{$\mathrm{ZrCu}$ 基合金马氏体相变温度与价电子经验图谱}

高卫红, 孟祥龙, 宋钢兵, 蔡伟, 赵连城

摘要 本文建立了一个关于马氏体相变温度和价电子数及电子浓度的经验图谱并设计了一系列 $\mathrm{ZrCu}$ 基形状记忆合金. 这些相变温度包括了所有 报道过的经 $\mathrm{Ni} 、 \mathrm{Co} 、 \mathrm{Hf} 、 \mathrm{Ag} 、 \mathrm{Ti} 、 \mathrm{Al} 、 \mathrm{Cr}$ 等掺杂替换 $\mathrm{Zr}$ 或者 $\mathrm{Cu}$ 原子的约 40 种合金. 反映了转变温度和电子浓度或者电子密度之间的关系. 结果显 示 $\mathrm{ZrCu}$ 基合金的转变温度逐渐下降, 当 $c_{\mathrm{v}}>0.218$ 时, 相变温度急剧下降. $\mathrm{ZrCu}$ 基合金的马氏体相变温度与电子密度呈线性关系. 基于相变温度 和滞后图谱的结果可以设计出在不同条件下工作的 $\mathrm{ZrCu}$ 基合金. 